\title{
OPTIMALISASI CITRA PERGURUAN TINGGI SWASTA MELALUI PENGUATAN INTERELASI PEMASARAN JASA SATUAN PENDIDIKAN
}

\author{
Oleh: \\ Taufani Chusnul Kurniatun, Elin Rosalin \\ Universitas Pendidikan Indonesia \\ (Email: taufani711@gmail.com )
}

\begin{abstract}
ABSTRAK:
Penelitian ini bertujuan untuk mengungkapkan peran kinerja bauran pemasaran jasa pendidikan (fasilitas fisik dan proses) dan dampaknya terhadap citra perguruan tinggi. Metode penelitian yang dilakukan menggunakan pendekatan survei lapangan. Sample dalam penelitian ini adalah mahasiswa perguruan tinggi swasta yaitu sebanyak 130 orang dengan menggunakan teknik convenience sampling. Analisis data dan pengujian hipotesis dijalankan dengan menggunakan analisis regresi dan perangkat lunak SPSS Versi 21,0 for windows. Hasil penelitian ini menunjukkan bahwa aspek bauran jasa pendidikan memiliki peran signifikan dalam membentuk citra perguruan tinggi. Untuk kinerja pemasaran dalam bauran fasilitas fisik dan bauran proses berpengaruh terhadap citra perguruan tinggi. Citra perguruan tinggi adalah pandangan, impresi, perasaan, konsepsi mahasiswa mengenai kegiatan operasional pendidikan mulai dari input, proses, output berorientasi pada segi layanan yang langsung di rasakan mahasiswa sebagai penerima jasa, dimana mungkin mempengaruhi langsung atau tidak langsung. Implikasi dari penelitian ini diarahkan untuk pengembangan strategi lembaga di segitiga pemasaran jasa dengan mengacu pada aspek bauran pemasaran jasa dan implikasi manajerial khusus dalam mengelola perguruan tinggi.
\end{abstract}

Kata Kunci: Bauran Pemasaran Jasa, Citra Perguruan Tinggi, Layanan Pendidikan dan Layanan Segitiga Pemasaran.

\section{ABSTRACT:}

This research seeks to reveal the role of performance of educational service marketing mix (physical facilities and processes) and their impact on the university image. This research was conducted by using field survey approach. Data taken from private university students as many as 130 people using convenience sampling technique. Data analysis and hypothesis testing is run by using regression analysis and SPSS software Version 21.0 for windows. The results of this study indicated that the aspect of educational service mix has a significant role in shaping the university image. For marketing performance in the physical facilities mix and process mix affect the university image. The image is emphasizing on the students' point of views, impressions, feelings, conceptions toward the operational activities of education ranging from input, process, output oriented in terms of service directly in the sense of students as recipients of services, which may affect directly or indirectly. Finally, the implications of this study are directed to the development of institutional strategies in service marketing triangles with reference to the marketing service mix aspect and the specific managerial implications in managing universities.

Keywords: Educational Service, Marketing Triangle Service, Service Marketing Mix, University Image,

\section{PENDAHULUAN}

Calon mahasiswa dan orang tua mereka menggunakan cukup banyak informasi untuk mengambil keputusan dalam memilih perguruan tinggi yang tepat (Moogan, 2011), ini merupakan proses pengambilan keputusan yang memakan waktu lama karena mempertimbangkan banyak faktor yang mungkin berbeda antara calon mahasiswa yang satu dengan yang lainnya. Hal ini menjadi masalah bagi orang tua dan calon mahasiswa dalam menemukan menemukan perguruan tinggi yang tepat yang sesuai dengan kebutuhan mereka, dari sekian banyak program pilihan yang ditawarkan oleh pihak perguruan tinggi. Dalam situasi di mana ada banyak sekali program pilihan atau merek, konsumen tidak bisa memeriksa semua merek secara rinci, jadi mereka cenderung fokus pada produk yang ditawarkan (Ballantyne et al 2006). Universitas yang bisa membedakan diri mereka dengan menciptakan citra merek yang kuat diakui oleh calon mahasiswa dan orang tua menjadi kriteria selama proses pengambilan keputusan dalam memilih perguruan tinggi (Mark Speece, 2016). Citra merek memiliki pengaruh yang cukup besar terhadap perilaku konsumen (Loudon and Della Bitta, 1995).

Dengan demikian citra adalah prediksi keputusan konsumen untuk melakukan kontak dengan organisasi (Gatewood et al, 1993). 
Disamping Membangun citra (image) menjadi jalan keluar bagi perguruan tinggi agar mampu berdaya saing ((Parameswaran and Glowacka, 1995; Ghosh et al, 2001; Beerli Palacio et al, 2002), dan untuk itu perlu berbagai upaya di tempuh untuk membangun citra perguruan tinggi. Program pemasaran dapat memainkan peran penting dalam brand image (Hoeffler dan Keller, 2002). karakteristik jasa pendidikan sejauh ini merupakan jasa yang memiliki intensitas kontak yang tinggi dengan penggunanya, yaitu penyedia jasa melakukan interaksi aktif dengan publik khususnya publik selaku peserta didik. Pada kondisi jasa seperti ini aktivitas pemasaran menjadi salah satu alternatif untuk membangun citra perguruan tinggi, pemasaran dirancang untuk meningkatkan peluang konsumen memiliki anggapan dan perasaan positif terhadap jasa atau produk (Landdrum et al, 1998; Peter dan Olson, 2000; Kottler, 2003; Alma dan Hurryati, 2009). Di sisi lain hal ini tentu dapat mempengaruhi intensi perilaku pelanggan jasa pendidikan.
Terkait implementasi bauran pemasaran dengan meningkatkan citra positif di ungkap oleh beberapa hasil penelitian yaitu: (1) Service Marketing Mix memiliki pengaruh signifikan terhadap citra merek dan dampaknya pada keputusan pembelian peserta lembaga kursus dan pelatihan royal english toefl \& toeic center (Lelyana dkk, 2015). (2) terdapat pengaruh positif variabel service marketing mix terhadap variabel citra department store (Dahmiri, 2010). (3) hasil peneltian Dedek K. Gultom bahwa Bauran pemasaran jasa (produk, biaya pendidikan, tempat, proses, orang, bukti fisik) berpengaruh terhadap kepuasan mahasiswa (Zeithaml and Bitner, 2003). Kotler dan Fox (2000). Oleh karena itu tujuan penelitian ini adalah (1) bagaimana bauran pemasaran jasa dalam penyampaian jasa pendidikan; (2) bagaimana citra perguruan tinggi dalam proses penyampaian jasa pendidikan; (3) pengaruh bauran pemasaran jasa dalam penyampaian pemasaran jasa pendidikan terhadap citra perguruan tinggi baik secara bersama sama maupun terpisah.

\section{METODE PENELITIAN}

Penelitian ini adalah penelitian dengan menggunakan metode survey untuk dapat menjelaskan hipotesis yang dibangun. Studi ini dilakukan pada perguruan tinggi swasta di Indonesia, Terdapat kurang lebih 10 perguruan tinggi swasta di Kota Bandung Indonesia yang mewakili dengan sampel adalah mahasiswa yang dipilih berdasarkan teknik non probability sampling tipe convenience sampling (Creswell, 2012). Adapun alat pengumpul data adalah kuesioner.

Peneliti melakukan analisis deskriptif untuk mengetahui profil responden, untuk mengukur hubungan antar variabel diolah dengan metode analisis regresi. Analisis dibantu dengan menggunakan Statistic Program Social Science (SPSS) versi 21.0 for Windows. Digunakan metode ini dengan pertimbangan terdapatnya hubungan-hubungan antar variabel yang terjadi secara bersamaan. Analisis regresi linear berganda mengestimasikan besarnya koefisien-koefisien yang dihasilkan oleh yang bersifat linear yang melibatkan dua variabel bebas untuk digunakan sebagai alat prediksi besarnya nilai variabel tergantung.

Adapun model penelitian ini adalah sebagai berikut:
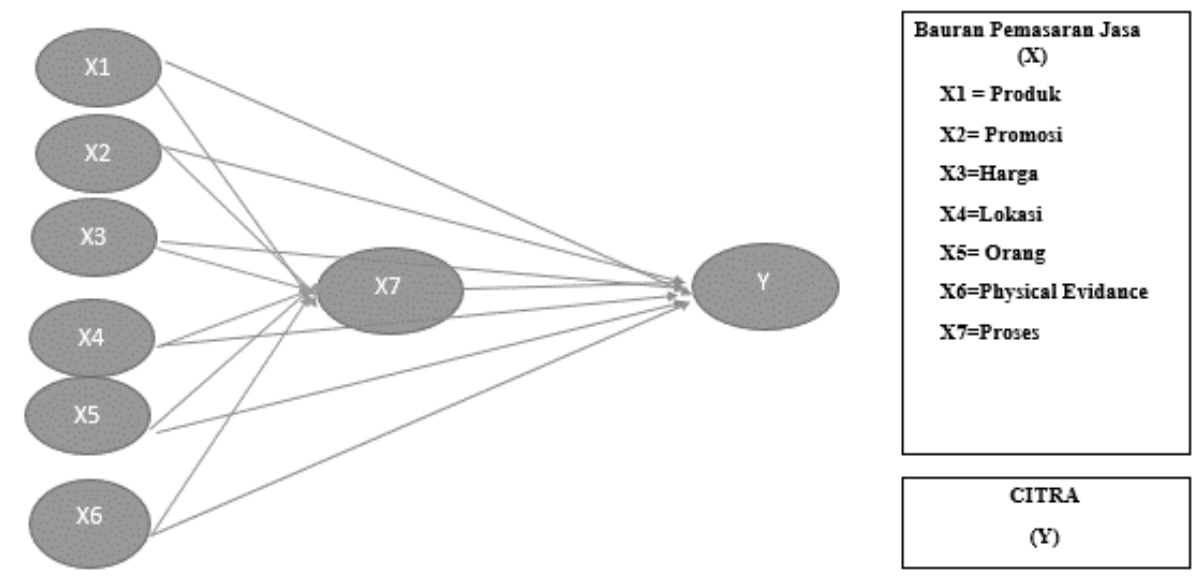
1. Gambaran Umum Bauran Pemasaran dan Citra Perguruan Tinggi

Gambaran umum mengenai variabel $X$ (Bauran Pemasaran Jasa Pendidikan) dan Y (Citra Perguruan Tinggi swasta) dapat diketahui melalui teknik perhitungan Weighted Means Score (WMS) yang bertujuan untuk mengukur kecenderungan umum skor responden. Gambaran umum bauran pemasaran perguruan tinggi swasta berdasarkan hasil penelitian adalah sebagai berikut:

\section{Tabel 1}

Hasil Perhitungan WMS Variabel X

\begin{tabular}{|c|c|c|c|}
\hline No & Indikator & $\begin{array}{l}\text { Hasil } \\
\text { WMS } \\
\end{array}$ & Keterangan \\
\hline \multicolumn{2}{|c|}{$\begin{array}{c}\text { Bauran Pemasaran Jasa } \\
\text { Pendidikan }\end{array}$} & $75,6 \%$ & Baik \\
\hline 1 & Visi misi lembaga & $79,4 \%$ & Baik \\
\hline 2 & $\begin{array}{l}\text { Peraturan/kebijakan } \\
\text { Akademik }\end{array}$ & $75,2 \%$ & Baik \\
\hline 3 & Reputasi produk & $79,8 \%$ & Baik \\
\hline 4 & $\begin{array}{l}\text { Variasi pilihan } \\
\text { Produk }\end{array}$ & $80,2 \%$ & Baik \\
\hline 5 & $\begin{array}{l}\text { Diferensiasi } \\
\text { Produk/ciri khas } \\
\text { produk }\end{array}$ & $71,5 \%$ & Baik \\
\hline 6 & Prosepek Produk & $75,6 \%$ & Baik \\
\hline 7 & $\begin{array}{l}\text { Mata kuliah } \\
\text { (Produk nyata) }\end{array}$ & $75,4 \%$ & Baik \\
\hline 8 & $\begin{array}{l}\text { Silabus (produk } \\
\text { nyata) }\end{array}$ & $74,4 \%$ & Baik \\
\hline 9 & Program Unggulan & $74,4 \%$ & Baik \\
\hline \multirow[t]{2}{*}{10} & $\begin{array}{l}\text { Sistem informasi } \\
\text { manajamen }\end{array}$ & $76 \%$ & Baik \\
\hline & Bauran Produk & $76,22 \%$ & Baik \\
\hline 11 & Coorporate design & $85 \%$ & Sangat Baik \\
\hline 12 & $\begin{array}{l}\text { Promosi informasi } \\
\text { kampus }\end{array}$ & $81 \%$ & Baik \\
\hline 13 & $\begin{array}{l}\text { Kegiatan Hubungan } \\
\text { kemasyarakat }\end{array}$ & $72 \%$ & Baik \\
\hline 14 & $\begin{array}{l}\text { Promosi penjualan } \\
\text { (informasi beasiswa }\end{array}$ & $80 \%$ & Baik \\
\hline \multicolumn{2}{|r|}{ Bauran Promosi } & $79,6 \%$ & Baik \\
\hline 15 & $\begin{array}{l}\text { Keterjangkauan } \\
\text { biaya }\end{array}$ & $70 \%$ & Baik \\
\hline 16 & $\begin{array}{l}\text { Prosedur } \\
\text { Pembayaran }\end{array}$ & $74 \%$ & Baik \\
\hline 17 & $\begin{array}{l}\text { Keseusaian biaya } \\
\text { pendidikan dengan } \\
\text { produk pendidikan, } \\
\text { fasilitas dan layanan } \\
\text { yang di terima }\end{array}$ & $71 \%$ & Baik \\
\hline & uran Harga & $72 \%$ & Baik \\
\hline
\end{tabular}

Lokasi Strategis

(kemudahan

18 mencapai lokasi dan $84 \% \quad$ Sangat Baik tersedia tranportasi

umum

Lokasi dekat dengan pusat kota

19 ,lingkungan belajar $\quad 71 \% \quad$ Baik dan kondisi lahan parkir

\begin{tabular}{|c|c|c|c|}
\hline & Bauran lokasi & $78 \%$ & Baik \\
\hline 20 & $\begin{array}{l}\text { Kompetensi } \\
\text { akamedik dosen }\end{array}$ & $78 \%$ & Baik \\
\hline 21 & $\begin{array}{l}\text { Kompetensi } \\
\text { penguasaan dalam } \\
\text { metode mengajar }\end{array}$ & $76 \%$ & Baik \\
\hline 22 & Kedisiplinan Dosen & $72 \%$ & Baik \\
\hline 23 & $\begin{array}{l}\text { Isi Materi } \\
\text { perkuliahan }\end{array}$ & $77 \%$ & Baik \\
\hline 24 & $\begin{array}{l}\text { Kompetensi } \\
\text { administrator dalam } \\
\text { pelayanan } \\
\text { pengeololaan } \\
\text { perguruan tinggi }\end{array}$ & $67 \%$ & Baik \\
\hline 25 & $\begin{array}{l}\text { Komptensi pegawai } \\
\text { memberikan } \\
\text { informasi }\end{array}$ & $70 \%$ & Baik \\
\hline & Bauran Orang & $73 \%$ & Baik \\
\hline 26 & $\begin{array}{l}\text { Desain ekterior, } \\
\text { desain interior } \\
\text { menarika }\end{array}$ & $75 \%$ & Baik \\
\hline 27 & $\begin{array}{l}\text { Kelengkapan } \\
\text { fasilitias penunjang } \\
\text { dan ruangan }\end{array}$ & $72 \%$ & Baik \\
\hline \multicolumn{2}{|c|}{ Bauran Fasilitas Fisik } & $74 \%$ & Baik \\
\hline 28 & $\begin{array}{l}\text { Proses } \\
\text { Pembelajaran }\end{array}$ & $78 \%$ & Baik \\
\hline 29 & Proses Pelayanan & $76 \%$ & Baik \\
\hline & Bauran Proses & $77 \%$ & Baik \\
\hline
\end{tabular}

Dari hasil pengolahan WMS, temuan penelitian pada bauran pemasaran jasa PTS di Kota Bandung berada pada kategori baik dengn skor presentase $76,5 \%$ hasil ini berdasarkan perhitungan atas hasil tiap indikator bauran pemasaran jasa (produk, harga, promosi, lokasi, orang, fasilitas dan proses). Hasil perolehan terendah ada pada bauran harga dengan perolehan skor $72 \%$, hal ini di peroleh dari perhitungan Weighted Means Score (WMS) tiap indikator bauran harga menunjukkan bahwa perguruan tinggi swasta memiliki kinerja bauran harga yang barorientasi pada mahasiswa seperti keterjangkauan biaya, kesederhanaan 
prosedur pembayaran, dan kesesuaian biaya yang diberikan dengan fasilitas yang diterima.

Adapun nilai tertinggi yaitu pada indikator bauran promosi, berdasarkan pada hasil perhitungan Weighted Means Score (WMS) sebesar 79,6\%, hal ini menunjukkan bahwa perguruan tinggi swasta memiliki kinerja bauran promosi yang mampu menarik perhatian mahasiswa dengan memberikan informasi, mempengaruhi dan menawarkan berbagai produk yang dimiliki perguruan tinggi swasta tersebut melalui media cetak, elektronik dan online.

Gambaran umum citra perguruan tinggi swasta berdasarkan hasil penelitian adalah sebagai berikut.

Tabel 2

Konsultasi Hasil Perhitungan WMS Variabel Y

\begin{tabular}{|c|c|c|c|}
\hline No & Pertanyaan & $\begin{array}{l}\text { Hasil } \\
\text { WMS }\end{array}$ & Kategori \\
\hline & CITRA & $75 \%$ & Baik \\
\hline 30 & Input kompetensi mahasiswa & $75 \%$ & Baik \\
\hline 31 & $\begin{array}{l}\text { Input kompetensi dosen } \\
\text { keilmuan, metode mengajar, } \\
\text { kedisiplinan }\end{array}$ & $79 \%$ & Baik \\
\hline 32 & $\begin{array}{l}\text { Input Tenaga administrasi } \\
\text { dan staf }\end{array}$ & $72 \%$ & Baik \\
\hline 33 & $\begin{array}{l}\text { Input kurikulum } \\
\text { pembelajaran (bahan ajae, } \\
\text { silabus, matakuliah yang } \\
\text { diterapkan pada perguruan } \\
\text { tinggi }\end{array}$ & $78 \%$ & Baik \\
\hline \multirow[t]{2}{*}{34} & $\begin{array}{l}\text { Pandangan Mahasiswa } \\
\text { terhadap input sarana/ } \\
\text { fasilitas } \\
\text { (kelengkapan.kenyaman, dan } \\
\text { keamanan }\end{array}$ & $73 \%$ & Baik \\
\hline & Citra Input & $75 \%$ & Baik \\
\hline 35 & $\begin{array}{l}\text { Proses Pembelajaran dan } \\
\text { Penilaian }\end{array}$ & $77 \%$ & Baik \\
\hline 36 & $\begin{array}{l}\text { Proses pelayanan responsive } \\
\text { dan antisipatif terhadap } \\
\text { kebutuhan serta memiliki } \\
\text { akuntabilitas }\end{array}$ & $69 \%$ & Baik \\
\hline 37 & $\begin{array}{l}\text { Proses transparasi manajerial } \\
\text { kampus }\end{array}$ & $70 \%$ & Baik \\
\hline & Citra Proses & $74 \%$ & Baik \\
\hline 38 & $\begin{array}{l}\text { Ketepatan kelulusan } \\
\text { mahasiswa }\end{array}$ & $74 \%$ & Baik \\
\hline 39 & $\begin{array}{l}\text { Pandangan dunia } \\
\text { kerja/industri terhadap } \\
\text { lulusan atau alumni kampus }\end{array}$ & $79 \%$ & Baik \\
\hline & Citra Output & $76 \%$ & Baik \\
\hline
\end{tabular}

Berdasarkan pada hasil perhitungan Weighted Means Score (WMS) variabel Y memperoleh skor $75 \%$. hasil ini berdasarkan perhitungan atas hasil tiap indikator citra perguruan tinggi terdiri dari citra input, proses output, Hasil nilai terendah pada indikator variabel $\mathrm{Y}$ yaitu pada citra proses dengan skor $74 \%$, Hal ini menunjukkan bahwa kinerja proses pada perguruan tinggi swasta seperti proses pelayanan yang mengedepankan aspek kemudahan, kesederhanaan prosedur, kejelasan, ketepatan dalam memberikan informasi dan cepat tanggap terhadap keluhan mahsiswa dalam hal pelayanan. Selain itu dari sisi proses pembelajaran seperti proses belajar di kelas (sistematis, mudah dipahami, menyenangkan), proses ujian proses dalam pembimbingan akademik, jadwal akademik yang berorientasi pada rencana mutu pendidikan perguruan tinggi itu sendiri. Serta mencoba untuk transparansi dari sisi proses pengelolaan pendidikan seperti transparansi penilaian, pembelajara, alokasi dana yang secara umum di kerluarkan oleh mahasiswa, trasparansi ketercapaian kualitas manajemen mutu yang sudah dicapai. Dengan berbagai upaya tersebut akan menumbuhkan kepuasaan, kepercayaan dan citra positif mahasiswa akan proses pendidikan yang dirasakan mahasiswa

Perolehan nilai tertinggi dari variabel Citra ini terdapat pada indikator citra output yaitu $76 \%$. Hal ini menunjukkan bahwa output pada perguruan tinggi swasta seperti ketepatan kelulusan mahasisiwa dan pandangan baik dunia industri terhadap lulusan alumni PTS yang telihat pada kerja sama yang diadakan oleh masingmasing PTS dengan dunia industri menjadi gambaran bahwa lulusan PTS di pandang baik oleh dunia industri atau kerja.

Dari pengujian normalitas data yaitu varibel $\mathrm{X}$ dan $\mathrm{Y}$ berdistribusi normal dan uji linieritas juga menunjukkan bahwa variabel $\mathrm{X}$ dan $\mathrm{Y}$ adalah linier

\section{Pengaruh Bauran pemasaran Terhadap Citra} Perguruan Tinggi

Menurut pengolahan statistik menemukan bahwa efek dari bauran pemasaran ke proses adalah sebagai berikut: 
Tabel 3.

Pengaruh Bauran Pemasaran terhadap Proses (X1-X6 hingga X7)

\begin{tabular}{|c|c|c|c|c|c|c|c|}
\hline \multirow[b]{2}{*}{ Model } & \multicolumn{2}{|c|}{ Unstandardized Coefficients } & \multirow{2}{*}{$\begin{array}{c}\text { Standardized } \\
\text { Coefficients } \\
\text { Beta }\end{array}$} & \multirow[b]{2}{*}{$t$} & \multirow[b]{2}{*}{ Sig. } & \multicolumn{2}{|c|}{$\begin{array}{c}95.0 \% \text { Confidence Interval } \\
\text { for B }\end{array}$} \\
\hline & $\mathrm{B}$ & Std. Error & & & & $\begin{array}{l}\text { Lower } \\
\text { Bound }\end{array}$ & Upper Bound \\
\hline 1 (Constant) & .570 & .613 & & .931 & .354 & -.643 & 1.783 \\
\hline Product to $\mathrm{X} 7$ & .037 & .027 & .148 & 1.383 & .169 & -.016 & .090 \\
\hline Promotion to $\mathrm{X} 7$ & .098 & .039 & .196 & 2.493 & .014 & .020 & .175 \\
\hline Price to $\mathrm{X7}$ & .068 & .054 & .084 & 1.253 & .213 & -.039 & .174 \\
\hline Location to $\mathrm{X} 7$ & .125 & .069 & .131 & 1.811 & .073 & -.012 & .261 \\
\hline People to $X 7$ & .094 & .033 & .260 & 2.825 & .006 & .028 & .160 \\
\hline $\begin{array}{l}\text { Physical facilities } \\
\text { to X7 }\end{array}$ & .135 & .078 & .149 & 1.732 & .086 & -.019 & .288 \\
\hline
\end{tabular}

Berdasarkan Tabel 3 ditemukan bahwa semua faktor adalah prediktor untuk proses dalam bauran pemasaran universitas swasta. Artinya produk, promosi, harga, lokasi, orang dan fasilitas fisik berpengaruh positif terhadap proses. Jika produk, harga, promosi, lokasi, fasilitas fisik dan orang meningkat atau ditambahkan maka prosesnya juga akan meningkat dalam kualitas. Namun, berdasarkan hasil uji signifikansi tidak ada pengaruh yang signifikan antara faktor yang diteliti (semua nilai signifikan>0,05) Dapat diasumsikan bahwa telah terjadi efek autokorelasi, karena prosesnya merupakan bagian dari bauran pemasaran. Selanjutnya, peneliti menurunkan tingkat kepercayaan menjadi $90 \%$ atau 0,1 . Jika nilai kepercayaan diturunkan menjadi $90 \%$ maka ada pengaruh yang signifikan yaitu lokasi, orang dan fasilitas fisik. Kemudian, pengaruh proses terhadap citra ditemukan bahwa proses memiliki efek positif dan signifikan terhadap citra universitas swasta. Dengan demikian hasil penelitian ini sesuai dengan beberapa penelitian sebelumnya yaitu layanan Bauran Pemasaran memiliki dampak yang signifikan terhadap merek dan pelatihan pusat TOEFL \& TOEIC Kerajaan Inggris (Lelyana dkk, 2015), bauran pemasaran layanan (produk, biaya pendidikan, tempat, proses, orang, evolusi fisik) mempengaruhi kepuasan siswa (Zeithaml dan Bitner, 2003), bauran pemasaran layanan (Dahmiri, 2010)), Kotler dan Fox (2000). Namun demikian model penelitian ini ada kelemahan dengan dugaan terjadinya korelasi otomatis, sehingga dalam penelitian selanjutnya model penelitian perlu ditingkatkan.

\section{SIMPULAN DAN REKOMENDASI}

Berdasarkan hasil penelitian dapat dilihat bahwa aspek dalam bauran pemasaran layanan universitas swasta, faktor-faktor yang memiliki pengaruh positif dan signifikan terhadap proses adalah lokasi, orang dan fasilitas fisik. Sedangkan prosesnya memiliki dampak positif dan signifikan terhadap citra perguruan tinggi swasta. Ini menunjukkan bahwa untuk meningkatkan citra, universitas swasta perlu memprioritaskan lokasi strategis, dosen dan personel yang berkualitas, serta fasilitas dan infrastruktur fisik yang memadai.
Ini akan mengarah pada proses layanan yang lebih baik sehingga citra perguruan tinggi swasta juga menjadi baik. Dengan demikian, untuk mengoptimalkan citra universitas swasta, harus dilakukan upaya: memilih lokasi kampus yang strategis, mengembangkan sumber daya manusia (dosen dan tenaga administrasi) dan meningkatkan fasilitas kampus, terutama untuk kegiatan belajar mengajar dan kegiatan siswa. Ini akan meningkatkan kualitas proses layanan dan pada akhirnya meningkatkan citra universitas swasta. 


\section{DAFTAR PUSTAKA}

Alma, Buchari. (2003) Pemasaran Stratejik Jasa Pendidikan. Bandung: Alfabeta.

Alma, Buchari dan Hurriyati, Ratih. (2009). Manajemen Corporate dan Strategi Pemasaran Jasa Pendidikan Fokus Pada Mutu dan Layanan Prima. Bandung: PT.Remaja Rosdakarya.

Alma, Buchari. (2013) Manajemen Pemasaran dan Pemasaran Jasa. Bandung: Alfabeta.

Alma, Buchari. (2004). Manajemen Pemasaran dan Pemasaran Jasa. Bandung: Alfabeta

Gultom, DK. Ginting, Paham. Sembiring, Beby KF (2014). Jurnal Manajemen \& Bisnis Vol. 14 No. 01 April 2014.

Dahmiri. (2010). Pengaruh Bauran Pemasaran (Marketing Mix) Terhadap Citra Departement Store. Jurnal Penelitian Universitas Jambi Seri Humaniora. Volume 12, Nomor 2 Hal 71-76: Juli 2010

J, Paul Peter dan Olson. (2000). Perilaku Konsumen dan Strategi Pemasaran. Edisi 4 Jilid 1. Jakarta: Erlangga.

Jöreskog, Karl and Dag Sörbom (2004), LISREL8: Structural Equation Modeling with the SIMPLIS Command Language. Chicago: Scientific Software International.

-.(1996). LISREL8: User's Reference Guide. Chicago: Scientific Software International.

Kotler, Philip. (2003). Marketing Manajemen. 11 th ed. New Jersey: Prentice Hall..

Kotler, Philip. (2004). Manajemen Pemasaran: Analisis, Perencanaan, implementasi dan Kontrol, Edisi Sebelas. Alih Bahasa, Hendra Teguh. Jakarta: PT. Prenhallind.

Kotler, Philip \& Karen F.A, Fox. (2000). Strategic Marketing for Educational Institutions $2^{\text {nd }}$ Editions. New Jersey: Prentice-Hall, Inc.

Kotler, Philip dan Armstrong, Gary. 2006. Prinsipprinsip Pemasaran. Edisi Keduabelas. Jakarta: Erlangga.

Lelyana Hadi, Dewi. Kumadji, Srikandi. Dan Yulianto, Edi. (2015). Pengaruh Service Marketing Mix (Pemasaran Jasa) Terhadap Citra Merek Dan Dampaknya Pada Keputusan Pembelian. Jurnal Administrasi Bisnis (JAB) Vol.24 No.1 Juli 2015.

Lupiyoadi Rambat dan A.Hamdani. (2006). Manajemen Pemasaran Jasa Edisi 2, Jakarta: Salemba Empat
Lupiyoadi Rambat dan A.Hamdani. (2013). Manajemen Pemasaran Jasa Berbasis Kompetensi Edisi 3, Jakarta: Salemba Empat.

Rusadi Rulan, (2003). Manajemen Publik Relation Media Komunikasi, Konsep Dan Aplikasi, Jakarta: PT. Raja Grafindo Persada.

Swastha, Basu dan Hani Handoko (2000), Manajemen Pemasaran : Analisa Perilaku Konsumen, Yogyakarta: BPFE.

Swastha, Basu. (2000). Manajemen Pemasaran Modern, Yogyakarta: Liberty.

Sutisna. (2001). Perilaku Konsumen Dan Komunikasi Pemasaran, Bandung: PT Remaja Rosdakarya.

Badan Pusat Statistik. Jumlah Perguruan Tinggi 1, Mahasiswa, dan Tenaga Edukatif (Negeri dan Swasta) di Bawah Kementrian Pendidikan dan Kebudayaan Menurut Provinsi 2013/2014. Diakses dari: https://www.bps.go.id/linkTabelStatis/vie w/id/ 1839

Direktori Kopertis IV. Sebaran Data PTS Per Kota Di Lingkungan Kopertis Wilayah IV. Diakses dari: http://www.kopertis4.or.id/ idik/dirpts/gr afik

Hamzah. (2011). Manajemen Input, Proses, Output dan Outcome dalam Mengelola Pendidikan Persekolahan LPMP. Diakses dari http://hamzah-lpmp.blogspot.co. id/2011/09/manajemen-input-prosesoutput-dan.html

Pusat Data dan Statistik Pendidikan. Indonesia Educational Statistics In Brief. Diakses dari:http://kemdikbud.go.id/kemdikbud/d okumen/BukuRingkasanDataPendidikan/ Final-In-Brief-1112.pdf

Pangkalan Data Pendidikan Tinggi Kementerian Riset, Teknologi Dan Pendidikan Tinggi. Grafik Jumlah Perguruan Tinggi. Diakses dari:

http://forlap.ristekdikti.go.id/perguruan tinggi/homegraphpt

Zeithmal, Valarie A. and Bitner, Mary Jo. (2003). Service Marketing. Tata McGraw Hill Inc. Int'1 Edition, New York. 